PURBAwIdyA: Jurnal Penelitian dan Pengembangan Arkeologi p-ISSN: 2252-3758, e-ISSN: 2528-3618 Akreditasi LIPI No. 695/Akred/ P2MI-LIPI/07/2015

Vol. 7(1), Juni 2018, pp 1 - 20 DOI: https://doi.org/10.24164/pw.v7i1.261

\title{
RAGAM HIAS TEMBIKAR MATANO DAN KORELASINYA DENGAN TRADISI TEMBIKAR SAHUYN-KALANAY
}

Matano Pottery Decoration Motifs and It's Relation to the Sahuyn-Kalanay Pottery Tradition

\author{
Rr. Triwurjani \\ Pusat Penelitian Arkeologi Nasional \\ Jalan Raya Condet Nomor 4, Pejaten, Jakarta Selatan \\ E-mail: demplon1@yahoo.com \\ Naskah diterima 3 April 2018 — Revisi terakhir 26 Juni 2018 \\ Disetujui terbit 15 Juli 2018 - Tersedia secara online 1 Agustus 2018
}

\begin{abstract}
Matano is the name of a lake in the regency of Luwu, South Sulawesi. Matano is famous for the deepest lake in Southeast Asia $( \pm 590 \mathrm{~m})$ and the eighth-deepest in the world. In this lake and its surroundings are archaeological findings such as metal artifacts, potteries, and ceramics. The presence of potteries at Lake Matano Site and its surrounding areas is important to note in the attempt to gain knowledge to reveal an aspect of life at Lake Matano area. The problems encountered include the dispersion and relations among those pottery artifacts at the sites of Matano and the surrounding areas. Furthermore, we would like to know whether the existence of great traditions that flourished in Southeast Asia during the Palaeometallic period, which are thought to greatly influenced the pottery development in East Indonesia, such as the Sahuyn-Kalanay, also influenced the pottery tradition at Matano. Methods of analytical descriptive and laboratories on pottery shapes and decoration motifs were applied to understand one of the aspects of pottery manufacture. There are some similarities in shapes, decoration motifs, and manufacturing techniques with the Sahuyn-Kalanay tradition in term of surface treatment, particularly in incised, stamped, gouged, and sliced decorating techniques.
\end{abstract}

Keywords: decoration motifs, Sahuyn-Kalanay, Matano, decorating techniques, manufacturing techniques

\begin{abstract}
Abstrak
Matano adalah nama salah satu danau yang terdapat di Kabupaten Luwu, Sulawesi Selatan. Di danau ini dan sekitarnya terdapat tinggalan arkeologis, seperti artefak logam, tembikar, dan keramik. Kehadiran tembikar di situs Danau Matano dan sekitarnya penting dicermati sebagai salah satu upaya memperoleh pengetahuan dalam mengungkapkan salah satu aspek kehidupan di Danau Matano. Permasalahannya adalah bagaimana sebaran dan hubungan artefak-artefak termbikar tersebut di situs-situs di daerah Matano dan sekitarnya. Di samping itu, adanya tradisi besar yang berkembang di Asia Tenggara pada masa perundagian yang diduga sangat memengaruhi perkembangan tembikar di Indonesia Timur, seperti Sahuyn-Kalanay, apakah juga memengaruhi tradisi tembikar di Matano? Untuk mengetahui salah satu aspek pembuatan tembikar, digunakan metode
\end{abstract}


deskriptif analitis dan laboratoris terhadap beberapa sampel tembikar. Tujuannya adalah untuk mengetahui apakah tradisi tembikar Matano mempunyai hubungan dengan tradisi lain. Hasil analisis menunjukkan ada beberapa kesamaan dalam bentuk, pola hias, serta teknik-teknik hias gores, tera, cukil, dan iris, yang juga diterapkan pada penggarapan permukaan tembikar tradisi Sahuyn-Kalanay.

Kata kunci: ragam hias, Sahuyn-Kalanay, Matano, teknik hias, teknik pembuatan

\section{PENDAHULUAN}

Benda tembikar mempunyai peran penting bagi manusia, baik secara sosial maupun ekonomi. Sebagai sisa aktivitas manusia, artefak tembikar hampir selalu ditemukan di situs-situs arkeologi dunia. Artefak ini pertama kali dikenal pada masa bercocok tanam dan manusia mulai hidup menetap. Tembikar pada masa ini dibuat dengan tangan dan pembakarannya kebanyakan tidak sempurna sehingga tembikar yang dihasilkan mudah pecah, rapuh, dan tidak dapat bertahan lama. Kebanyakan tembikar yang dihasilkan pada masa bercocok tanam dalam keadaan rapuh dan menampilkan permukaan yang polos atau dengan hiasan sederhana berupa garis pendek (Soejono, 2008: 228-233).

Pada masa berikutnya, yaitu masa perundagian, masyarakat sudah mengenal kekhususan pekerjaan sesuai dengan keterampilan yang dikuasainya, seperti keterampilan khusus membuat tembikar (penganjun), pande logam, dan pande emas, dan masyarakat pada waktu itu sudah mempunyai struktur sosial dan sistem religi. Oleh karena itu, masa ini sering disebut dengan masa paleometalik (Soejono, 1984: 323). Dengan sendirinya masyarakat pada masa ini juga telah mempunyai struktur sosial yang teratur dan pembagian pekerjaan sesuai dengan keterampilan yang dikuasinya. Pada masa ini tingkat pembuatan tembikar juga sudah berkembang dengan dikenalnya roda putar dan teknik tatap landas. Permukaan tembikar diberi hiasan dengan berbagai corak, baik geometris, pola anyaman, pola tali, antropomorfik, slip, maupun hiasan lainnya. Pembuatan tinggalan ini, selain dengan teknik putaran tangan, juga menggunakan roda putar, dan tatap landas. Adapun persebaran situs-situs tembikar masa perundagian, antara lain Situs Buni di Bekasi, Situs Gilimanuk di Bali, dan Situs Kalumpang di tepi Sungai Karama, Sulawesi Selatan.

Berdasarkan hiasannya kebanyakan tembikar dengan pola geometris, oleh para ahli dikategorikan ke dalam masa perundagian, tembikar pada masa perundagian dianggap mempunyai banyak persamaan dengan tradisi tembikar Sahuyn-Kalanay (Solheim II, 1964:27-51; Soejono, 1969: 69-91; Soejono, 2008: 228233). Atas dasar itu, kehadiran tembikar tersebut diasumsikan sebagai benda-benda yang dibawa oleh orang-orang berpenutur Austronesia yang melakukan migrasi dari daerah asal di Taiwan ke daerah lainnya.

Hipotesis ini dibuat oleh Wilhelm G. Solheim, seorang ahli antrpologi Amerika yang mempelajari pergerakan artefak dan perpindahan orang berpenutur Austronesia yang tersebar di Asia Tenggara melalui studi bahasa dan tembikar. Hasil penelitian Solheim menunjukkan bahwa tradisi tembikar-tembikar di situs Sahuyn, Vietnam dan situs Kalanay, Filipina mempunyai banyak persamaan sehingga sering disebut sebagai tradisi SahyunKalanay dan pada umunya tinggalan 
budaya itu ditemukan dalam konteks kubur, ada yang ditemukan sebagai wadah kubur (jar burial) ataupun sebagai bekal kubur (funeral gift) (Solheim II, 1965:254-273).

Solheim juga mengemukakan bahwa sudah ada pergerakan artefak melalui jaringan maritim (perdagangan) oleh orang-orang yang tinggal di Asia Tenggara melalui wilayah Filipina, Vietnam, Pesisir Cina Selatan, Taiwan, dan melalui dataran Sunda (Sunda land) sejak 5000 tahun yang lalu. Pergerakan ini bolak-balik dalam jaringan maritim yang terkenal dengan NMCNT (Nusantao Maritime and Coomunication Network), Jaringan perdagangan dan komunikassi maritim Nusantao (Solheim II, 1996: 101109; Flessen, 2006). Nusantao itu sendiri berasal dari bahasa Austronesia, nusa artinya 'selatan' dan tao artinya 'orang (people)' (Solheim II, 1959: 97-188; (Solheim II, 1985: 77-88).

Danau Matano terletak dekat dengan Danau Malili dan Danau Mahalona, dan termasuk ke dalam wilayah Kabupaten Luwu, Sulawesi Selatan. Di anatara ketiga danau yang berdekatan ini, Danau Matano adalah yang paling panjang, mencapai 28 $\mathrm{km}$. Di sekitar Danau Matano terdapat Kota Sorowako yang merupakan kota tambang nikel yang konon termasuk kota tambang yang bagus di dunia. Pertambangan nikel ini dikuasai oleh PT INCO yang berafiliasi di Canada, Amerika Serikat. Informasi bahwa daerah Matano sebagai penghasil logam sudah dikenal sejak lama, seperti yang tersebut dalam Nagarakrtagama, pupuh 14, yang menyebutkan utusan dari Majapahit berkunjung Ke Luwuk untuk membeli senjata, seperti keris dan parang (Muljana, 2006:236). Berita pengangkatan benda arkeologis dari dalam danau pun telah dipelopori oleh para penyelam Danau
Matano pada kedalaman tertentu yang antara lain menghasilkan benda logam, seperti kapak corong, senjata berupa keris, dan tembikar. Berita penemuan kemudian ditindaklanjuti dengan penelitian arkeologi yang dilakukan pada tahun 2016 (Adhityatama, 2016; Adhiyatama, 2017).

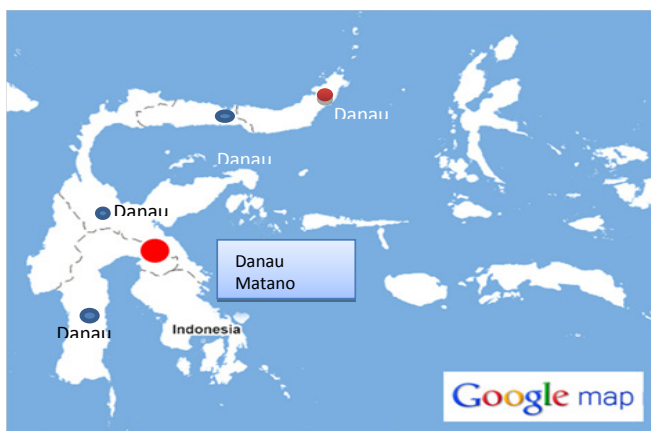

Peta 1. Keletakan Danau Matano (Sumber: Google Map 30312017 dengan Modifikasi)

Penelitian di daerah sekitar Danau Matano juga disinggung oleh David Bullbeck dkk. pada tahun 2000 serta Balai Arkeologi Makasar tahun 2008. Hasil penelitian tersebut antara lain menyebutkan bahwa penemuan tembikar di situs-situs di sekitar Danau Matano menunjukkan adanya indikasi tembikar prasejarah dari masa paleometalik. Penelitian David Bullbeck bersama proyek OXIS (Results of the Origin of Complex Society in South Sulawesi Project, yang diterbitkan oleh Centre for South-East Asian Studies, University of Hull dan School of Archaelogy and Anthropology, Australian National University; terfokus pada masalah peradaban logam (besi) yang pernah ada di Matano. Pembicaraan mengenai tembikar baru sebagian disinggung oleh Bullbeck dan kawankawan. Bulbeck dan Ian Caldwell yang telah melakukan eksplorasi di daerah Luwu dan sekitarnya pada tahun 2000 
menyatakan bahwa daerah Matano adalah penghasil besi terbaik, yang tidak saja memenuhi untuk kebutuhan lokal bahkan untuk kawasan Asia Tenggara (Bulbeck \& Prasetyo, 1998: 29-42; Bullbeck \& Caldwell, 2000: 1-33; Somba, 2008).

Pada tahun 2016 Pusat penelitian Arkeologi Nasional mengadakan penelitian Bawah Air di Danau Matano. Selain itu, juga diadakan eksplorasi di daratan dengan melakukan survei di situssitus sekitar danau. Wilayah survei dapat dibagai dalam dua area, antara lain area di dalam danau Matano yaitu situs Pulo Ampat, Pontada dan Sedengkuro, dan di area daratan di sekar danau Matano antara lain situs Gua Pulo Ampat, Gua Tengkorak, Gua Andomo, Gua Tuasade, Situs mata air Borri-borri dan situs Kompleks Makam Mokole. Penelitian arkeologi bawah air ini meskipun masih bersifat awal, berdasarkan hasil analisis pada benda-benda temuan arkeologi baik di dalam danau maupun di daratan, menunjukkan bahwa Danau Matano sudah dihuni cukup lama sejak zaman prasejarah. Mereka menetap dan hidup di lingkungan danau mendekati sumber air untuk keberlangsungan hidupnya. Pada kehidupan yang sudah menetap inilah biasanya masyarakatnya pun berkembang (Adhityatama et al., 2016; Adhiyatama et al., 2017: 37-49). Dengan demikian, masih sedikit informasi yang diperoleh tentang budaya Matano, apalagi diketahui bahwa tanah Matano mengandung besi dan ditemukanya sejumlah artefak tembikar di beberapa situs di daerah ini. Oleh karena itu, kehadiran tembikar di Matano perlu dicermarti sebagai sisa aktivitas manusia masa lalu dan juga sebagai petunjuk akan pentingnya benda tembikar tersebut bagi masyarakat pendukungnya pada waktu itu.
Sampel tembikar sengaja dipilih untuk diteliti lebih lanjut, mengingat tidak semua temuan tembikar dapat diangkat dari dalam danau, begitu pula tidak semua temuan pecahan tembikar dapat diambil dari situs-situs yang terdapat di darat, seperti gua dan tepi pantai.

Permasalahannya adalah hampir di setiap situs-situs ditemukan benda tembikar sehingga mengemuka pertanyaan bagaimanakah persebaran tembikar di situs-situs tersebut dan apakah tembikartembikar tersebut mempunyai pengaruh antara tradisi tembikar Sahuyn-Kalanay dengan tradisi tembikar di Matano? Penelitian ini bertujuan untuk mengetahui ada atau tidaknya pengaruh tersebut pada tradisi tembikar di Matano. Manfaat dari kajian ini adalah diketahui salah satu aspek kehidupan dan cara-cara hidup manusia pada waktu itu, seperti teknik membuat tembikar dan mengetahui sumber bahan serta latar belakang keberadaan tembikar di Matano. Manfaat lainnya adalah sebagai upaya menambah data dalam merekonstruksi sejarah kebudayaan Matano secara khusus dan menemukenali kembali peradaban Matano yang pernah hilang.

\section{METODE}

Tahap pertama adalah dilakukan pengumpulan data, baik data kepustakaan maupun data lapangan. Data lapangan yang dikumpulkan berupa artefak tembikar yang merupakan hasil survei bawah air dan darat. Pengambilan sampel terpilih ini sengaja dilalukan mengingat di wilayah tersebut belum pernah dilakukan ekskavasi. Jumlah sampel yang berhasil dikumpulkan ada 46 pecahan dan 5 dalam bentuk utuh dan setelah beberapa pecahan dapat disambung, jumlahnya menjadi 44 
pecahan. Pecahan-pecahan ini ada yang polos dan ada pula yang mempunyai hiasan pada bagian permukaannya.

Tahap kedua adalah tahap analisis benda tembikar, baik dalam bentuk utuh maupun dalam bentuk pecahan dengan mengamati pengggarapan permukaan. Dalam hal ini akan diuraikan mengenai pola hias dan teknik penerapan pada tembikar Matano sehingga dikenali apa yang menjadi ciri dari tembikar Matano. Pada pengamatan pola hias ini juga sekaligus diamati cara penerapannya, seperti ada satu pola hias yang dibuat dengan beberapa teknik tertentu. Ada beberapa teknik pembuatan pola hias, antara lain teknik cukil, congkel (gouging), iris/potong (sliced, cut), teknik gores (insicing), teknik tera /cap (stamping), teknik tempel (applique), teknik tusuk (puncture). Ada pula yang diberi alur pada bagian badan sebagai akibat dari proses peghalusan permukaaan (grooved), diserut (scrapped), atau diukir (carved) (Shepard, 1965: 49-65; Rangkuti, Pojoh, \& Harkantiningsih, 2008).

Tahap ketiga adalah dengan metode komparatif, yaitu melakukan perbandingan, melihat persamaanpersamaan dan perbedaan-perbedaan pada variabel yang menjadi ciri dari setiap tradisi antara Matano dan SahuynKalanay. Untuk memperkuat interpretasi, juga dilakukan analisis laboratoris dengan alat XRF (X-Ray Fluoresence) untuk mengetahui kandungan unsur-unsur yang ada di dalamnya dan sumber bahan. $X R F$ adalah teknik analisis unsur yang membentuk suatu material dengan dasar interaksi sinar-X dengan material analit. Teknik ini banyak digunakan dalam analisis batuan karena hanya memerlukan jumlah sampel yang relatif sedikit (sekitar
1 gram) (Viklund, 2008).

\section{HASIL DAN PEMBAHASAN Bentuk Tembikar Matano}

Berdasarkan hasil pengamatan bentuk pecahan dan bentuk utuh serta variabel ukuran, diperoleh gambaran bentuk-bentuk Tembikar Matano, antara lain tempayan, periuk: 21. Bentuk wadah utuh ada 5 buah. Jumlah lainnya dalam bentuk pecahan yang terdiri atas tempayan: 3 ; mangkuk: 4 ; tutup wadah: 1 ; cawan : 1; cawan berkaki tinggi seperti pedupaan (incene burner): 15; cepuk: 1; piring: 1. Seperti benda tembikar pada umumnya, penggarapan permukaaan Tembikar Matano dimaksudkan selain untuk mengurangi rembesan air, juga supaya wadah bertambah kuat, tidak mudah pecah. Teknik penggarapan permukaaan ini dilakukan dengan slip dan upam, sedangkan untuk menambah keindahan juga dibuat lukisan dan diberi hiasan dengan motif geometris, baik dengan cara gores, iris, temple, ataupun diukir. Teknik slip dilakukan dengan mengoleskan cairan dari batuan sedimen lainnya, dapat berwarna merah atau hitam, dikenakan pada keadaan tembikar masih dalam keadaan basah sebelum dilakukan pembakaran.

\section{- Periuk}

Periuk adalah jenis wadah tembikar dengan diameter mulut lebih kecil daripada badan. Dengan perbedaan ukuran tersebut biasanya periuk disebut sebagai wadah tertutup (Soegondho, 1995). Tembikar jenis periuk ini paling banyak dan paling sering ditemukan jika dibandingkan dengan bentuk-bentuk tembikar lainnya di situs-situs arkeologi. Bentuk periuk di antaranya ada yang bulat besar dan 
mengecil pada bagian atasnya dan ada juga yang berbentuk bulat lonjong dengas alas agak datar (lihat lampiran 1 gambar 1.). Ukuran wadah rata-rata mempunyai tinggi $20 \mathrm{~cm}$, dengan diameter mulut 11$-16,5 \mathrm{~cm}$. Ada juga yang mempunyai ukuran tinggi $18 \mathrm{~cm}$.

Berdasarkan hasil pengamatan dari jejak pembuatannya, periuk dibuat dengan tangan dan tatap landas. Teknik yang digunakan adalah gabungan teknik pilin (coiling) dan pijit (pinching) serta putaran tangan (hand throwing). Penggarapan permukaan, selain dengan cara upam, ada juga yang diberi slip. Fungsinya adalah selain mengurangi rembesan air juga agar tampilan benda menjadi lebih indah, apalagi ditambah dengan hiasan dengan motif-motif tertentu. Tidak semua permukaan benda periuk diberi hiasan, tetapi hanya pada bagian leher atau badan bagian atas. Warna tembikar bervariasi, ada warna abu-abu terang (light yellowish brown 10YR.6/4); merah keabua-abuan (pinkish gray 7,5R-7,1), dan abu-abu kehitaman (gray 7.5YR6.1). Periuk biasanya digunakan segbagai wadah untuk memasak, kadang-kadang juga digunakan sebagai bekal kubur (burial gift). Periuk ini berasal dari dalam Danau Matano, yang sengaja diambil oleh para penduduk yang pada awalnya menyelam mencari benda logam.

\section{- Tempayan}

Benda tempayan bentuknya hampir sama dengan periuk, hanya ukurannya lebih besar (diameter badan dapat mencapai 40 $\mathrm{cm}$ ), dan termasuk dalam wadah tertutup. Ukuran tempayan biasanya lebih besar jika dibandingkan dengan wadah-wadah tembikar lainnya. Pengamatan terhadap bentuk pecahan menunjukkan bahwa benda ini dibuat dengan teknik tangan dengan cara menempelkan adonan bahan yang telah diuleni pada benda yang sedang dibuat dengan teknik pijit (pinching dan coiling). Teknik lain yang digunakan adalah putaran tangan (hand throwing) dan tatap landas. Pecahan tempayan ini ditemukan di Gua Tengkorak dan Gua Andomo. Dekat pecahan tempayan tersebut terdapat temuan tulang belulang, sisa manusia berserakan, beberapa manikmanik, dan pecahan keramik dan benda logam. Menurut penjaga gua, benda logam, seperti parang dan pisau, sudah hilang diambil oleh penduduk setempat untuk diperbaiki dan dijual kembali.

\section{- Mangkuk (Bowl)}

Mangkuk termasuk jenis wadah terbuka dengan lebar mulut lebih lebar daripada lebar badan atau ada juga yang hampir sama lebarnya. Mangkuk mempunyai badan bulat dan bagian dasarnya berbentuk datar, serta pada ujung membentuk cekungan. Bagian dasar biasanya mempunyai kaki pada bagian luarnya. Ukuran mulut mangkuk rata-rata mempunyai diameter 14--16 cm dengan tinggi $9--10 \mathrm{~cm}$ dan tebal $0,5--0,7 \mathrm{~cm}$. Pengamatan terhadap bentuk pecahan tampak wadah ini dibuat dengan teknik pilin (coiling) dan pijit (pinching), putaran tangan (hand throwing), dan tatap landas, serta diberi slip merah. Adapun lokasi situs penemuan benda ini terdapat di Situs Gua Tengkorak, Gua Pulo Ampat, dan Gua Andomo.

\section{- Tutup Wadah}

Sesuai dengan fungsinya sebagai penutup wadah, benda ini mempunyai bentuk cekung dan pada bagian atasnya mempunyai pegangan. Permukaan bagian 
luar tampak halus, seperti diupam dan diberi slip. Pengamatan terhadap jejak pembuatan menunjukkan benda ini dibuat dengan putaran tangan (hand throwing) yang kemudian dipadukan dengan teknik tatap landas. Bagian permukaannya diupam dan diberi slip sehingga tampak halus. Tutup wadah dengan warna coklat (weak red $10 \mathrm{R} 3 / 4$ ) ini mempunyai tekstur yang rapat dan temper yang halus. Tutup ini mempunyai ukuran tinggi $8 \mathrm{~cm}$ dengan diameter $18,5 \mathrm{~cm}$, dan tebal tepian 0,6 $\mathrm{cm}$. Sementara itu, bagian pegangannya mempunyai ketebalan $0,9 \mathrm{~cm}$ dan mempunyai ukuran tinggi $2,5 \mathrm{~cm}$. Hanya ada satu sampel tutup yang diperoleh, yaitu dari situs Gua Pulo Ampat.

\section{- Pedupaan (Incene Burner)/Cawan Berkaki Tinggi}

Cawan berkaki tinggi atau pedupaan merupakan wadah terbuka yang mempunyai kaki tinggi (Soegondho, 1995). Biasanya wadah bagian atas adalah tempat sesuatu untuk dibakar. Oleh karena itu, sering disebut dengan pedupaan. Fungsi lain dari benda ini adalah sebagai tempat saji. Di daerah Luwu benda seperti ini disebut dengan addupang atau paddupang atau ada juga disebut dengan dapo-dapo, yaitu wadah pembakar dupa yang terbuat dari tanah liat dan merupakan salah satu alat pelengkap dalam upacara ritual (Idwar, 2007: 3). Benda jenis ini sampai sekarang masih digunakan sebagai tempat untuk menyajikan makanan, seperti di daerah Sulawesi Selatan dengan bentuk dan variasi yang sedikit berbeda, hanya saja terbuat dari logam atau dari bahan lain.

Pengamatan bagian pecahannya menunjukkan benda ini dibuat dengan teknik pijit (pinching) dan pilin (coiling) yang kemudian dipadukan dengan teknik roda putar. Bagian permukaan ada yang diupam dan diberi slip serta diberi motif hias. Tinggi kaki wadah rata $11--12 \mathrm{~cm}$, dan diameter kaki 14--16 cm.

Jika dilihat dari bahannya, benda ini mempunyai temper halus dan permukaanya pun tampak halus. Wadah ini mempunyai warna coklat, 7.5 YR 2,5/2 very dark brown) dan kehitaman, (7.5 YR 2.5/1 black). Cawan berkaki terdapat di situs Pulo Ampat, Potanda, Sedengkuro, Gua Tengkorak, dan Gua Tuasade. (Lihat lampiran 1 Gambar 2)

\section{- Cawan}

Cawan termasuk wadah terbuka, dengan diameter mulut lebih besar daripada diameter badan dan tidak mempunyai leher (Soegondho, 1995). Cara membuatnya adalah dengan teknik gabungan pilin (coiling) dan pijit (pinching) serta putaran tangan (hand throwing) dan diberi slip. Cawan ini mempunyai diameter mulut 13 $\mathrm{cm}$ dan tinggi $4,5 \mathrm{~cm}$. Wadah ini hanya ditemukan di Situs Mokole.

\section{- Tutup Cepuk}

Cepuk adalah jenis wadah kecil yang mempunyai tutup. Bagian tutup dan wadah merupakan bagian yang terpisah, tidak menyatu (Wahyudi, 2012). Bagian tutup cepuk mempunyai diameter $10 \mathrm{~cm}$ dengan tebal $0.6 \mathrm{~cm}$, dan berwarna merah kecoklatan (5 YR 3/4. dark reddish brown). Tutup cepuk mempunyai temper halus dan dibuat dengan teknik pijit (pinching) serta diberi slip. Temuan fragmen tutup cepuk terdapat di Gua Tengkorak

\section{- Piring}

Piring merupakan jenis wadah terbuka dengan bentuk agak datar dan 
dengan tepian terbuka yang lebar dan mempunyai diameter cukup besar, yaitu antara 20--25 cm, dan mempunyai ukuran tinggi kurang dari $3 \mathrm{~cm}$. Ada yang mempunyai kaki, ada pula yang tidak (Soegondho, 1995; Wahyudi, 2012). Pengamatan pada pecahan tembikar menujukkan bahwa benda tersebut dibuat dengan gabungan teknik lempeng (slabing) dan pijit (pinching) dan mungkin juga disempurnakan dengan putaran tangan (hand throwing). Bentuk piring ini terdapat di situs Mokole, Desa Matano dan pola seperti ini hanya terdapat di Situs Mokole, Desa Matano.

\section{Ragam Hias Tembikar Matano}

Untuk membuat motif hias pada permukaan tembikar, para penganjun biasanya menggunakan teknik-teknik tertentu, baik dikerjakan dengan alat maupun tanpa alat, seperti teknik gores (incised), cukil (excised), congkel (gouged), cap/tera (stamp) atau tekan (impressed), iris/potong (cut), teknik tempel (applique), dan teknik lukis (painting), ukir (carving) (Shepard, 1965:69). Berdasarkan analisis pola-pola hias tembikar Matano, diperoleh kurang lebih 32 jenis motif hias geometris. Adapun yang dimaksud dengan pola hias geometris adalah pola hias yang menggunakan motif dasar dari ilmu ukur, seperti unsur garis, bidang, atau ruang (KBBI, 2016). Unsur geometris tersebut antara lain adalah garis, garis lurus, lengkung, zig-zag, spiral, dan berbagai bidang, seperti segi empat, persegi panjang, lingkaran, layang-layang, titik, koma, lingkaran, dan belah ketupat. Pola hias yang terdapat pada Tembikar Matano antara lain adalah sebagai berikut.

\section{- Pola Garis Mendatar}

Pola ini mempunyai dua variasi, antara garis mendatar berjajar, dan garis mendatar berganda. Pada benda tertentu kadang-kadang pola ini ada yang digabungkan dengan pola lain sehingga membentuk motif berbeda yang merupakan gabungan dari unsur-unsur geometris. Pola garis ini biasanya diterakan di bagian tepian, tengah, ataupun bagian leher dari wadah. Pola ini dibuat dengan cara menggores bagian wadah dengan alat tertentu, dengan alat yang tajam, atau dengan teknik tekan yang menggunakan cangkang kerang sehingga dihasilkan garis mendatar yang putus-putus. Pola hias ini terdapat di situs Gua Tengkorak, Gua Tuasade, Gua Pulo Ampat, dan hampir seluruh situs di Matano.

\section{- Pola Garis Melengkung}

Penerapan pola garis melengkung mempunyai variasi garis lengkung berjajar dan garis lengkung berganda. Garis melengkung ini biasa diterakan di bagian leher dan tepian wadah; biasanya sebagai pembatas antara satu bidang hiasan dengan bidang hiasan lainnya atau sebagai bingkai dalam suatu pola hias tertentu. Pola ini dihasilkan dengan teknik gores. Pola hias ini hampir selalu ada di tembikar hias di setiap situs di Matano.

\section{- Pola Garis Tegak Vertikal}

Pola garis tegak vertikal kebanyakan merupakan garis tegak pendek-pendek berjajar ataupun secara berganda yang membatasi pola hias lainya dan diterakan pada bagian leher, pundak, atau bagian tangah wadah. Pola hias ini hampir selalu ada di tembikar hias pada setiap situs di Matano. 


\section{- Pola Garis Miring/Diagonal}

Pola garis miring atau diagonal banyak mempunyai variasi, seperti garis miring sejajar, garis miring ganda, ataupun garis miring membentuk segitiga terbuka seperti tumpal. Biasanya pola garis miring ini diterakan pada bagian leher wadah, seperti pada leher periuk. Pola hias ini digabungkan dengan pola titik yang mengikuti alur garis miring tersebut. Pola hias ini hampir selalu ada pada setiap Situs di Matano.

\section{- Pola Garis Zig-Zag}

Pola garis zig-zag sepintas mirip dengan garis biku karena hampir sama bentuknya, yaitu merupakan garis yang digores secara berkesinambungan dengan arah yang zig-zag. Garis zig-zag mempunyai variasi garis zig-zag berganda atau lebih. Pola ini biasanya diterakan di bagian tepian, kususnya pada pedupaan atau cawan berkaki tinggi. Pola hias ini dibuat dengan teknik tera dengan kerang ataupun dengan alat lainnya. Pola yang diterakan di pedupaan ini berasal dari Situs Gua Tengkorak.

\section{- Pola Hias Titik}

Pola hias titik dibuat dengan cara tusuk dan gores, variasinya adalah garis titik berbentuk bulatan dan garis. Pola hias titik membentuk garis mempunyai variasi, antara lain titik membentuk garis datar, titik membentuk garis miring, dan titik membentuk garis tegak. Variasi lain adalah titik berbentuk bulat, titik berjajar, dan titik ganda berjajar. Pola hias titik dibuat dengan teknik tusuk dan variasi selanjutnya adalah dengan teknik tusuk dan gores. Pola hias ini ada di situs atau di tembikar-tembikar yang ditemulan di
Situs Pulo Ampat, Pontada, Gua Pulo Ampat, dan Gua Tengkorak.

\section{- Pola Hias Bulat}

Pola hias bulat dibuat dengan cara menggores atau menusuk dengan benda yang tajam dan membuat bulatan dapat merupakan hiasan bulatan yang apabila ditekan kuat dapat tembus membentuk lubang.Variasi dari pola hias ini adalah lubang bulat ganda berjajar, lubang segitiga dan lubang segi empat. Pola hias lubang segitiga tumpal dan segi empat ini dibuat dengan gabungan antara teknik tekan, iris, dan congkel (gouged and cut-out). Pola ini terdapat di Situs Gua Andomo.

\section{- Pola Tumpal Bergerigi}

Pola hias tumpal dengan cara mengiris atau memotong bagian tepian membentuk tumpal segitiga sehingga tampak bergerigi. Pola tumpal bergerigi ini cukup banyak terdapat pada wadah cawan berkaki tinggi, terutama pada bagian kaki. Pola hias ini banyak digunakan pada tembikar dari Situs Pontada, Pulo Ampat dan Gua Tegkorak.

\section{- Pola Hias Kuku}

Pola hias kuku dibuat dengan cara menancapkan kuku pada wadah tembikar yang masih basah. Seringkali motif ini digabungkan denagn motif hias pola tali (cordmark). Hiasan dengan pola ini digunakan pada bagian sambungan atau badan bagian atas. Pola hias kuku terdapat di Situs Pontada

\section{- Pola Hias Tali (Cord Mark)}

Pola hias tali dibuat dengan cara tali dibalutkan pada tatap, kemudian diterakan pada permukaan wadah dengan cara dipukul-pukul pada bagian tertentu 
atau keseluruhan dari wadah ketika masih basah sehingga terbentuklah suatu pola tali yang sebelumnya telah dibalutkan pada tatap tersebut. Variasi pola ini adalah pola tikar, anyaman, kotak-kotak, ataupun bentuk belah ketupat. Pola ini sering kali dikenal sebagai pola hias terajala dan banyak terdapat pada benda-benda jenis periuk di Situs Andomo, Gua Tuasade, Gua Pulo Ampat, dan di dalam Danau Matano.

\section{- Pola Hias Krawangan/Terawangan (Pola Ukiran Tembus)}

Pola hias seperti ukiran dibuat dengan cara mengukir benda tembikar sampai dengan menembus bidang dasar hingga membentuk lubang-lubang, dengan bentuk-bentuk geometris, gabungan antara garis diagonal, tumpal, biku dan zig-zag, serta titik bulat. Ukiran ini dibuat dengan cara mengiris, menembus benda tembikar sehingga menimbulkan lubang-lubang yang bentuknya sesuai dengan bentuk ukirannya, dalam hal ini pola gemetris. Pola ini mirip dengan pola hias krawangan atau terawangan atau yang biasa dipakai pada perhiasan ataupun sketsel (pembatas ruang) (inonesianewshome.wordpress. com diunduh 20318). Pola hias krawangan ini dikenakan pada bagian leher dari kaki pedupaan/cawan berkaki tinggi/pedupaan (incene burner) (lihat lampiran 1 gambar 3) . Benda dengan motif hias geometris krawangan ini berasal dari Situs Pontada di dalam danau.

\section{- Pola Hias Ceplok Bunga}

Berdasarkan hasil pengamatan pada pembuatan hiasan pada beberapa penganjun yang masih ada di beberapa daerah di Sulawesi Selatan, pola hias bentuk bunga ini biasanya dibuat dengan menempelkan adonan yang masih basah pada wadah lalu dibentuk sedemikian rupa membentuk susunan kelopak bunga. Pola hias ini merupakan gabungan antara teknik tempel (apllique) dan pijit/pencet (piching). Pola hias ceplok bungan ini terdapat di Situs Mokole.

\section{- Pola Hias Gelombang}

Pola hias gelombang dibuat dengan cara menekan jari tangan pada badan wadah sambil diputar sehingga membentuk bagian cekungan, baik ke dalam maupun ke luar seperti gelombang. Hiasan gelombang ini kemudian diberi slip untuk menyempurnakan bagian permukaan. Bagian dalam pecahan tembikar dengan pola hias ini juga dapat menunjukkan teknik pembuatan dengan roda putar yang tampak pada striasinya. Pecahan badan tempayan ini berasal dari Situs Gua Tengkorak.

\section{Penempatan Pola Hias}

Berdasarkan pengamatan pada bentuk dan teknik pola hias Tembikar Matano, terhadap sampel tembikar dan hampir semua pola hias tersebut dapat direkam melalui Gambar A. Gambar berikut adalah contoh hampir semua pola hiasTembikar Matano yang behasil digambar, antara lain pola hias tali berbentuk tikar, kotak-kotak, belah ketupat, dan anyaman pada gambar yang diberi nomor 1--4, serta pada bagian lampiran yang berisi contoh-contoh pola hias Tembikar Matano. Pola ini ada yang digabung dengan pola titik, biasanya terdapat pada bagian badan bagian atas atau badan keseluruhan. Pola hias garis diagonal dan titik, seperti pada gambar yang diberi nomor 5, 6, 7 terdapat di 
bagian leher periuk (lihat contoh-contoh pola hias Tembikar Matano pada Lampiran 1 gambar 4).

Pola hias lukis dengan memberi warna pada bidang tertentu (painting) juga sudah dikenal pada tradisi Matano. Pola hias titik berbentuk garis tegak, Nomor 8, dan pola titik garis mendatar dan diagonal, Nomor 22 dan 14, biasanya terdapat pada bagian tengah wadah. Begitu pula pada Nomor 11, 14, 17, 19--21 pola hias lukis terdapat pada bagian tengah mengeliligi wadah. Sementara itu, pola hias Nomor 10, 16, dan 18 adalah pola hias garis pendek vertikal dan zig-zag yang dikerjakan dengan teknik tera dengan menggunakan kerang.

Pola hias bergerigi juga terdapat pada bagian tepian dengan cara diiris dan dicongkel pada Nomor 32. Pola hias Nomor 23 adalah pola hias kuku dengan cara menekankan kuku pada badan bagian atas dekat leher wadah. Pola hias Nomor 24--29 dan 31 adalah pola hias pada tepian kaki wadah cawan berkaki. Pola hias Trawangan Nomor 30 yang dibuat dengan tekan dan iris serta congkel hingga menembus bidang wadahnya terdapat pada bagian kaki wadah cawan berkaki tinggi/pedupaan. Atas dasar itu, pola hias Tembikar Matano sebenarnya menerapkan pola hias dengan unsur geometris yang menjadi unsur dasar-dasarnya dengan berbagai teknik dan gabungan antara teknik-teknik tersebut (lihat Lampiran 1, Gambar 5, 6, dan 7).

\section{Analisis Unsur XRF}

XRF adalah kepanjangan dari $X$-Ray Fluoresence (XRF), yaitu suatu teknik analisis dengan bantuan Sinar $\mathrm{X}$ untuk mengetahui unsur pada suatu material. Metode XRF telah banyak dilakukan oleh para ahli karena prosesnya relatif lebih mudah. Kemudahnnya adalah analisis ini tidak memerlukan banyak sampel yang dibutuhkan minimal seberat satu gram, tidak merusak sampel serta prosesnya cepat. Prinsip kerja alat ini adalah menggunakan prinsip eksitasi dan emisi Sinar X elektron-elektron pada suatu atom atau unsur terkecil yang dianalisis (Viklund, 2008). Menurut Viklund (2008), apabila terjadi eksitasi Sinar-X primer yang berasal dari tabung $\mathrm{X}$ Ray atau sumber radioaktif(alat) mengenai sampel, Sinar- $X$ dapat diabsorpsi atau dihamburkan oleh material. Proses ketika Sinar-X diserap oleh atom dengan mentransfer energinya pada elektron yang terdapat pada kulit yang lebih dalam disebut efek fotolistrik. Emisi Sinar-X dihasilkan dari proses yang disebut $X$ Ray Fluorescence (XRF). Proses deteksi dan analisis emisi Sinar- $X$ disebut analisis XRF. Pada umumnya kulit $\mathrm{K}$ dan $\mathrm{L}$ terlibat pada deteksi XRF sehingga sering terdapat istilah $\mathrm{K} \alpha$ dan $\mathrm{K} \beta$ serta $L \alpha$ dan L $\beta$ pada XRF. Jenis spektrum $\mathrm{X}$ ray dari sampel yang diradiasi akan menggambarkan puncak-puncak pada intensitas yang berbeda (Viklund, 2008).

Sampel tembikar diletakkan pada posisi tertentu pada bagian atas alat XRF (tempat meletakkan sampel) ini, kemudian alat tersebut akan bekerja dan tidak lama kemudian akan terlihat susunan kandungan unsur dalam suatu material yang berupa tabel dan grafik.

Berdasarkan hasil analisis X-Ray (lihat Lampiran 2), pada beberapa sampel Tembikar Matano, terlihat bahwa unsur nikel (Ni) paling banyak terdapat dalam bahan material tembikar. Biasanya unsurunsur dominan dalam tanah liat adalah pasir, lempung, dan tentu saja unsur lainnya, seperti alumunium oksida $\left(\mathrm{Al}_{2} \mathrm{O}_{3}\right)$, 
silika $\left(\mathrm{SiO}_{2}\right)$, besi oksida $\left(\mathrm{Fe}_{2} \mathrm{O}_{3}\right)$, kalsium oksida $(\mathrm{CaO})$, dan natrium oksida $\left(\mathrm{Na}_{2} \mathrm{O}\right)$. Hasil analisis XRF, yaitu unsur nikel yang dominan, sebetulnya tidak lazim dalam bahan material tembikar pada umumnya. Akan tetapi, mengingat bahwa daerah sekitar Danau Matano mengandung bijih nikel, kandungan unsur ini menjadi hal yang wajar untuk wilayah Matano. Apalagi di desa (sekarang menjadi kota tambang) Sorowako yang terletak di sekitar Danau Matano telah dibangun perusahaan besar tambang nikel milik asing dari Canada sejak tahun 1968, yang bernama PT Vale Indonesia. Desa ini kemudian berkembang menjadi kota tambang, bahkan konon merupakan kota tambang yang terindah jika dibandingkan dengan kota-kota tambang di negara-negara lainnya.

Adanya temuan unsur nikel yang paling dominan yang mencapai lebih dari 43.000 ppm menunjukkan bahwa Tembikar Matano merupakan tembikar lokal, dibuat dan berasal dari tanah Matano sendiri.

\section{Sahuyn-Kalanay dalam Tradisi Matano}

Tradisi Sahuyn Kalanay dikenal sebagai tembikar dengan dominan pola hias geometris, seperti pola hias garis, titik, garis lengkung, garis miring, segitiga terbuka, belah ketupat, kotak-kotak, atau tikar yang menyerupai anyaman atau keranjang, garis melingkar yang disusun, yang semuanya dikenal dengan sebutan motif geometris. Pada umumnya teknik pembuatan tembikar dibuat dengan tatap landas dan roda putar lambat serta ditemukan dalam konteks kubur. Tatap dibungkus dengan tali sehingga yang dihasilkan adalah pola anyaman, tikar, segi empat, kotak-kotak, seperti bentuk tali pembalutnya dan pola hias tali (cord mark) menjadi salah satu ciri dari tradisi tersebut.
Tradisi ini muncul pada masa bercocok tanam sekitar abad 1000 SM--200 M (Solheim II, 2003:121). Menurut Soejono, tradisi tatap landas dengan teknik hias cord mark di Indonesia baru muncul pada masa perundagian, yaitu sekitar 200-400 M (Soejono, 2008:385-397). Jika dilihat dari teknik penyelesaian permukaan, tradisi ini dilakukan dengan teknik upam dan slip (Soegondho, 1995:87).

Berkaitan dengan adanya hubungan antara tradisi Matano dan Sahuyn-Kalanay, setelah mengamati hasil analisis Tembikar Matano, dapat diketahui ada beberapa persamaan dan perbedaan dengan tembikar Sahuyn-Kalanay, bahkan lebih banyak persamaannya, terutama dalam teknik pembuatan dan teknik penggarapan permukaan, seperti penerapan pola hias geometris dan slip, baik slip merah maupun hitam. Apabila dilihat dari tradisi lain di Indonesia yang telah mendapat pengaruh Sahuyn-kalanay terlebih dahulu, seperti di Kalumpang (Sulawesi Selatan) dan Gilimanuk (Bali), pola hias Tembikar Matano, seperti garis miring, garis biku, garis lengkung yang dterakan pada bagian leher wadah, dan juga pola tali yang diterapkan di hampir seluruh bagian permukaan mirip dengan tradisi Gilimanuk dan Kalumpang. Agaknya Matano juga termasuk salah satu daerah yang mendapat pengaruh tersebut. Jika dilihat dari konteksnya, yaitu umumnya tembikar dari tradisi ini ditemukan dalam konteks kubur, ada beberapa situs di Matano yang bukan berasal dalam konteks kubur, seperti Situs Pontada, Pulo Ampat, dan Sedengkuro. Situs-situs tersebut semuanya berada di dalam danau dan merupakan situs-situs bawah air dan diduga sebagai sisa permukiman kuno.

Hampir semua motif hias geometris 
tradisi Matano juga merupakan pola-pola hias yang menjadi ciri khas dari tradisi Sahuyn-Kalanay, seperti yang terdapat pada pola hias Nomor 1-19, 21, 23, 25, dan 32. Hasil pengamatan pada pola hias tampak bahwa motif hias Matano yang tidak atau belum muncul pada tradisi Sahuyn-Kalanay adalah motif trawangan pada Nomor 28 dan 30. Pengamatan pada teknik penyelesaian permukaaan adalah tampaknya Tembikar Matano lebih mempunyai variasi jika dibandingkan dengan tradisi tembikar Sahuyn-Kalanay. Variasi tersebut tampak pada gabungan berbagai pola hias geometris yang sesuai dengan peruntukannya, seperti pola hias bergerigi dengan teknik iris dan cukil yang diterakan pada bagian sekeliling tepian dengan teknik iris miring yang berlawanan sehingga menghasilkan tepian bergerigi.

\section{SIMPULAN}

Sebaran temuan tembikar hampir ditemukan di setiap situs di Danau Matano dan sekitarnya. Situs-situs tersebut antara lain Situs Pontada, Pulo Ampat dan Sedengkuro (di dalam danau), sedangkan sebaran situs di daratan terdapat di tepitepi danau, seperti Situs Gua Tengkorak, Gua Pulo Ampat, Kampung Kuno Matano, dan yang agak jauh dari danau, antara lain, Situs Kompleks Makam Mokole dan Gua Andomo.

Adanya korelasi yang dibuktikan dengan pengaruh tradisi Sahuyn-Kalanay dalam tradisi Matano menunjukkan bahwa ada hubungan antara orang-orang Matano dengan orang-orang dari luar Matano. Hubungan tersebut antara lain dibuktikan dengan adanya kesamaan dalam hal pada pola hias terawangan. pembuatan tembikar dan dalam penerapan penyelesaian permukaan. Latar belakang munculnya kesamaan tembikar Matano dan Sahuyn Kalanay tentu saja perlu dikaji lebih khusus lagi. Tembikar Matano bukan barang impor melainkan dibuat dari bahan baku yang berasal dari tanah di sekitarnya. Atas dasar itu, pembuat tembikar ini bisa jadi adalah orang-orang yang sudah lama menetap di perairan Danau Matano. Masyarakat danau ini tampaknya juga telah lama melakukan interaksi dengan orang-orang yang datang dari luar, baik datang melalui laut ataupun menyusuri sungai hingga pedalaman sebagai efek dari aktivitas jaringan maritim Nusantao. Dalam interkasi ini sangat dimungkinkan terjadi perkawinan antara penduduk pendatang dan penghuni lama, bahkan tinggal menetap di daerah tersebut akibat proses kawin mawin. Dalam interaksi inilah terjadi transfer pengetahuan ataupun kebiasaan-kebiasaaan yang secara tidak langsung dituangkan dalam membuat tembikar, baik bentuk maupun pada pembuatan pola hias, apalagi bahan baku tersedia di sekitarnya. Kemungkinan lain adalah bukan manusianya yang berpindah, melainkan bendanya yang bergerak seperti yang telah dibuktikan dalam jaringan Maritim Kuno Nusantao, sebagai barang komoditas yang diperjualbelikan sehingga dapat terjadi proses kreativitas dalam meniru ataupun mencontoh, terutama dalam pembuatan pola hias. Oleh karena itu, merupakan hal yang wajar apabila terdapat persamaan-persamaan, terutama dalam pola-pola hias dengan daerah asalnya meskipun unsur khas Matano tetap muncul, terutama yang diperlihatkan 


\section{DAFTAR PUSTAKA}

Adhityatama, S., Suryatman, Triwurjani, R., Utomo, B. B., \& Sulistyarto, P. (2016). Laporan Penelitian Arkeologi Eksplorasi Maritim di Danau Matano, Sorowako.

Adhiyatama, S., Triwurjani, R., Sulistyarto, P., Suryatman, \& Utomo, B. B. (2017). "Underwater Archaeological Study on Prehistoric Material Culture in Matano Lake, South Sulawesi, Indonesia." Southeast Asian Archaeology, 37, 37-49.

Bulbeck, D., \& Prasetyo, B. (1998). Survey of Pre-Islamic Historical Sites in Luwu, South Sulawesi. Walennae, 1(1), 29-42.

Bullbeck, D., \& Caldwell, I. (2000). Land of Iron The historical archaeological of Luwu and the Cenrena valley. OXIS, Centre for South-East Asian Studies University of Hull, School of Archaelogical and Anthropology Australian National University.

Flessen, C. 2006. (2006). Models of Neolithic movements of people in Southeast Asia and the Pacific.

Idwar, A. (2007). Ensiklopedi Kebudayaan Luwu. (p. 3). Penerintah Kota Palopo, Pemerintah Kabupaten Luwu Utara, Pemeritah Kabupaten Luwu Timur,.” PT. INCO.

kbbi. (2016). http://kbbi.web.id/representasi,.

Map, G. (2017). Pulau Sulawesi, diunduh 30132017 dengan modifikasi.

Muljana, S. (2006). Tafsir Sejarah Nagara Kretagama. Yogyakarta: LKiS.

Rangkuti, N., Pojoh, I., \& Harkantiningsih, N. (2008). Buku Panduan Analisis Keramik (cet ke-3). Jakarta: Pusat Penelitian dan Pengembangan Arkeologi Nasional, Badan Pengembangan Sumberdaya Kebudayaan dan Pariwisata, Departemen Kebudayaan dan Pariwisata.

Shepard, A. O. (1965). Ceramics for The Archaeologist. Washington D.C: Carnegie Institution of Washington.

Soegondho, S. (1995). Tradisi Gerabah di Indonesia dari Masa Prasejarah Hingga Masa Kini. Jakarta: Himpunan Keramik Indonesia.

Soejono, R. P. (1969). The History of Prehistoric Research in Indonesia to 1950. Asian Perspective, XII, 69-91.

Soejono, R. P. (1984). Sejarah Nasional Indonesia I (Zaman Prasejarah di Indonesia). Jakarta: P.N Balai Pustaka.

Soejono, R. P. (2008). Sejarah Nasional Indonesia I (Zaman Prasejarah di Indonesia). Jakarta: Departemen Pendidikan \& Kebudayaan P.N. Balai Pustaka.

Solheim II, W. G. (1959). "Sa-huynh Related Pottery in Southeast Asia". Asian Perspective, 3(2 (Special Issue)), 97-188.

Solheim II, W. G. (1964). The Archaeology of Central Philippines: A Study Chiefly of the Iron Age and Its Relationships. Manila: Manila: Bureu of Printing.

Solheim II, W. G. (1965). "The Function of Ceramics in Southeast Asia: From the Present to the Past." In F. M. (ed) (Ed.), Ceramic and Man (pp. 254-273). Chicago: Aldine: Wenner Gren Foundation for Anthropological Research, Viking Fund Publication in Anthropology.

Solheim II, W. G. (1985). The Nusantao Hypothesis: The Origin and Spread of 
Austronesian Speakers. Asian Perspective, 26(1), 77-88.

Solheim II, W. G. (1996). Bulletin of the Indo-Pacific Prehistory Association. Bulletin of the Indo-Pacific Prehistory Association., 15, 101-109.

Solheim II, W. G. (2003). "Southeast Asian Earthenware Pottery and Its Spread"

Earthenware in Southeast Asia Proceedings of the sian Ceramic Society, Singapore

University Press. p. 1-21.Singapore Symposium on Premodern Southeast Asian

Earthen ware. Southeast A. In J. N.Miksic (Ed.). Singapore: sian Ceramic Society,

Singapore University Press. p. 1-21.Singapore Symposium on Premodern

Southeast Asian Earthen ware. Southeast.

Somba, N., Hakim, B., Hasanuddin, Bernadeta, Mappainga, Slamet, \& Purnama, D.

(2008). Laporan Penelitian Arkeologi Atas Legenda Luwu Pada Zona-Zona

Toponim di Kabupaten Luwu Timur Sulawesi Selatan. Makassar.

Viklund. (2008). Teknik Pemeriksaan Material Menggunakan XRF, XRD dan SEM-EDS. Jakarta.

Wahyudi, W. R. (2012). Tembikar Upacara di Candi-Candi Jawa Tengah abad ke-8-10. Jakarta: Wedatama Widya Sastra. 
PURBawidya $\square$ Vol. 7, No. 1, Juni 2018: 1- 20

\section{Lampiran 1}
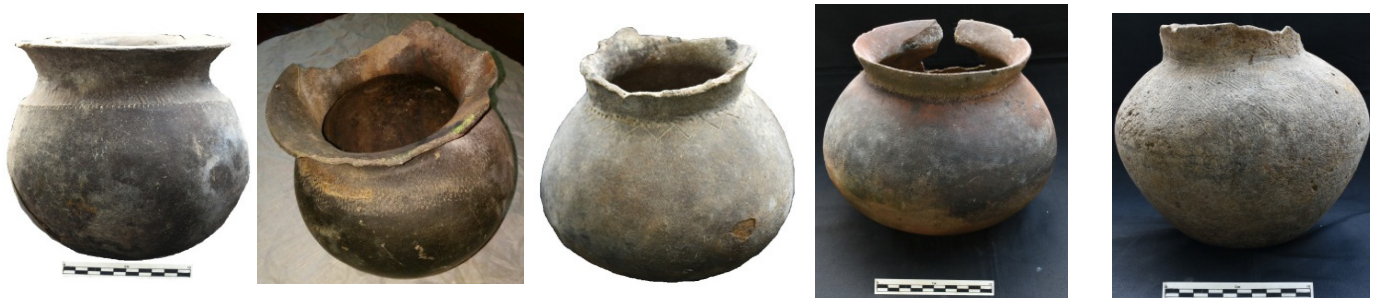

Gambar 1. Variasi Bentuk Periuk Utuh, Badan Bulat dan Bulat Lonjong (Sumber: Dokumen Triwurjani, 2018)
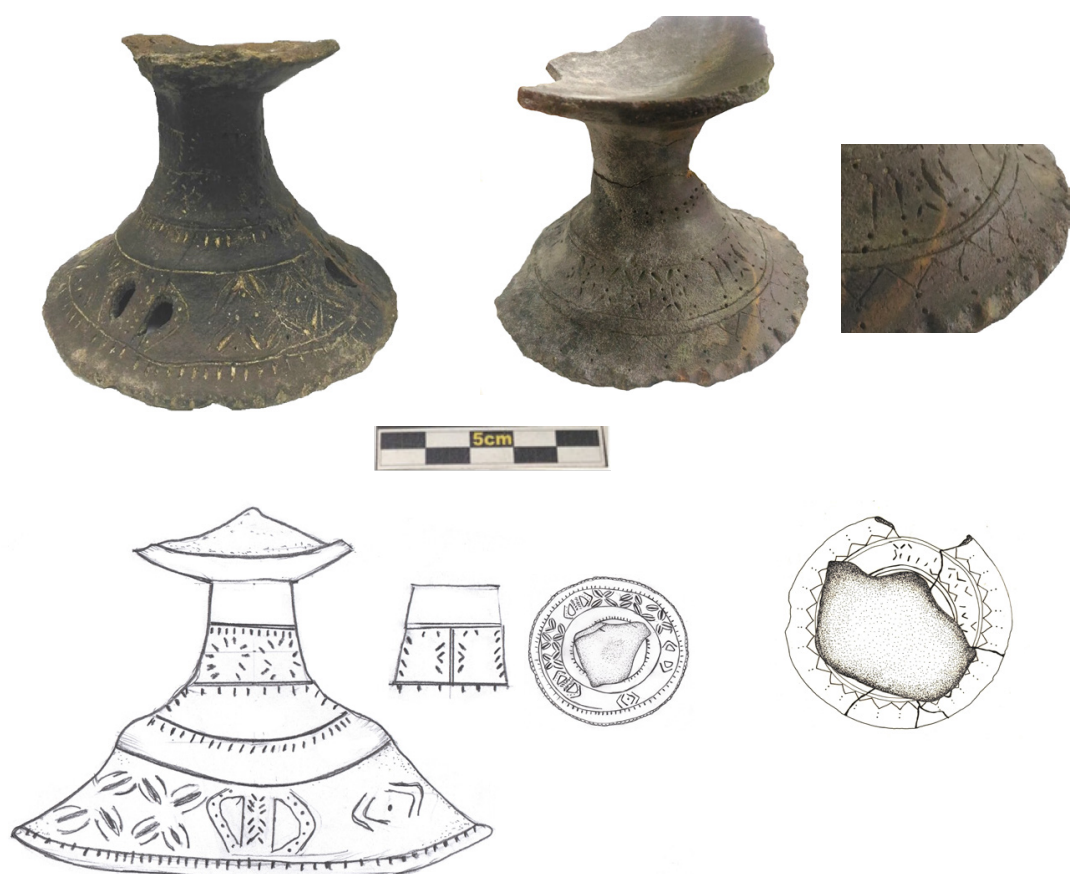

Gambar 2. Fragmen cawan berkaki tinggi/pedupaan (sumber: Dokumen Tim penelitian, 2016)
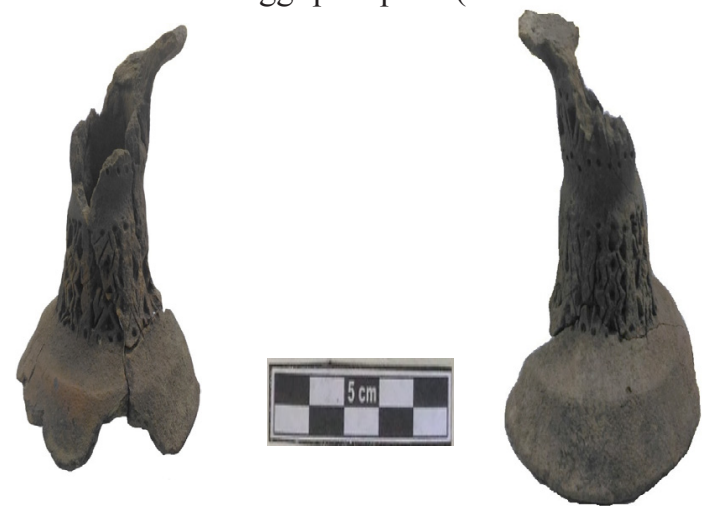

Gambar 3. Pola Hias Krawangan pada Fragmen Cawan Berkaki Tinggi/Pedupaan (Sumber: Rr. Triwurjani, 2108) 


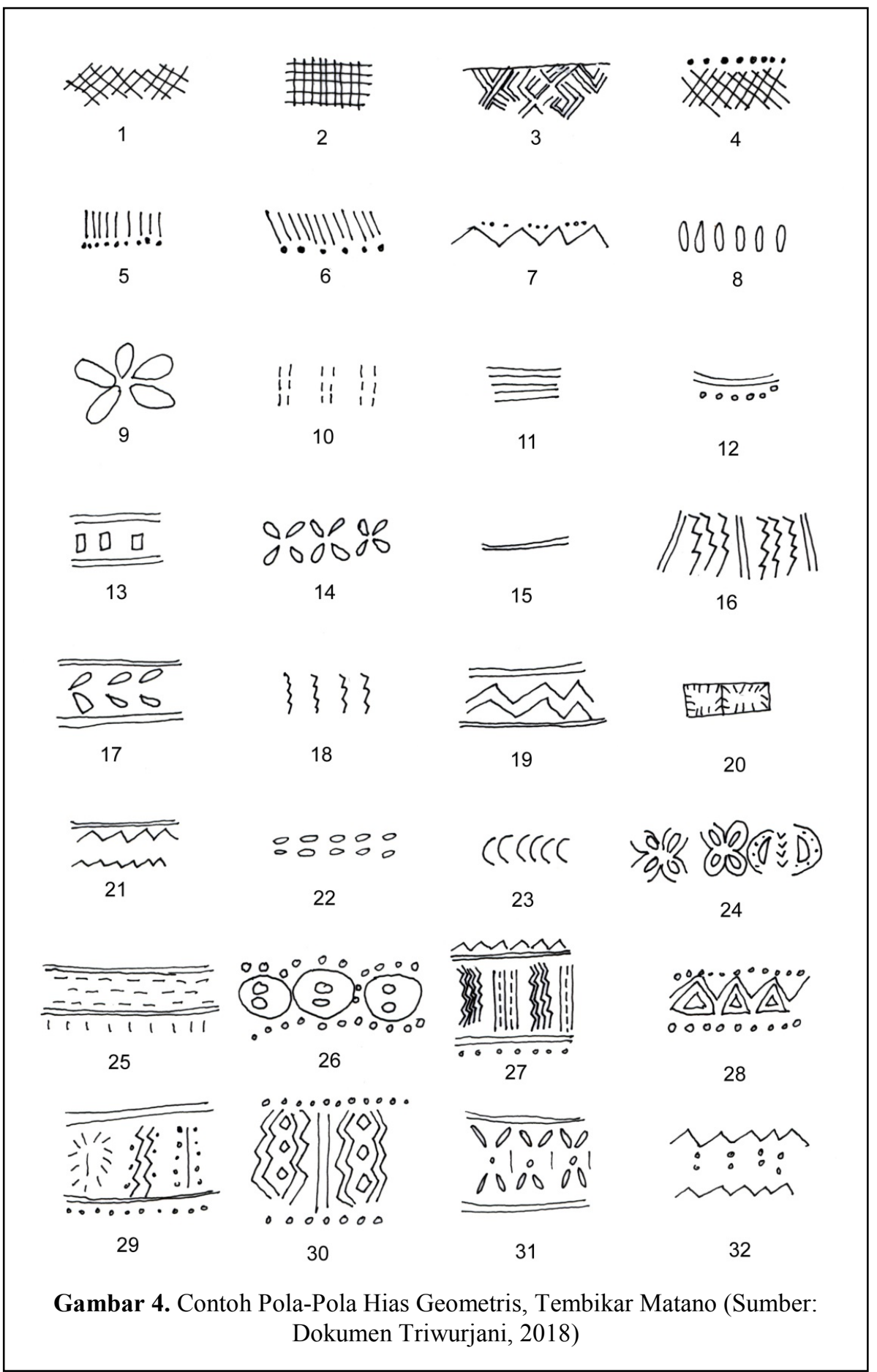




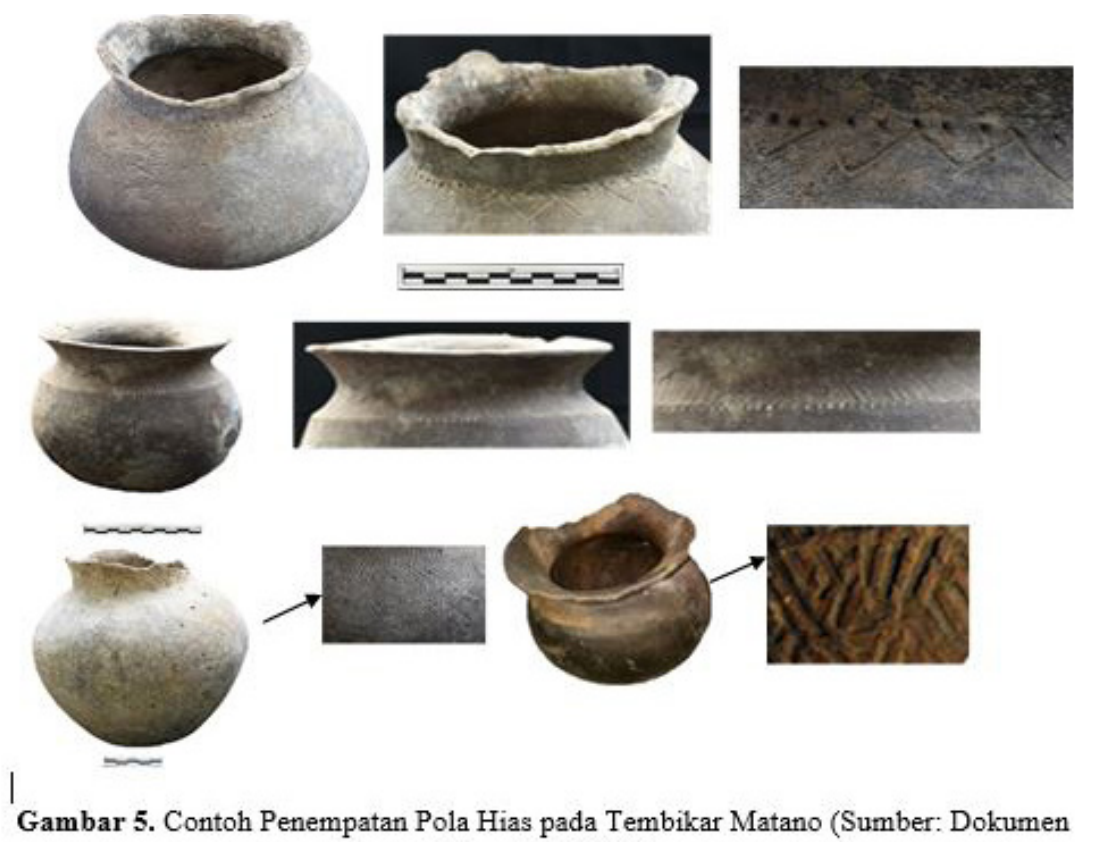

Gambar 5. Contoh Penempatan Pola Hias pada Tembikar Matano (Sumber: Dokumen Triwurjani, 2018)

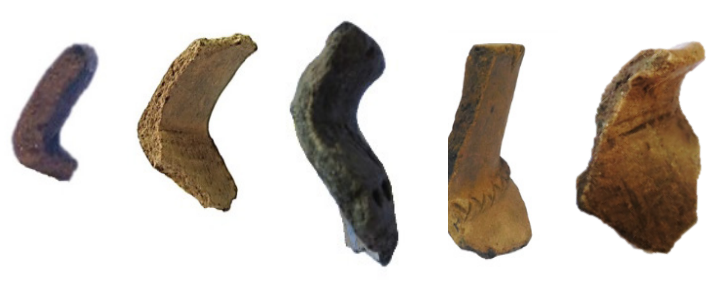

Gambar 6. Beberapa Tepian Wadah Terbuka yang Ditemukan di Daratan Matano (Sumber: Dokumen Triwurjani, 2018)

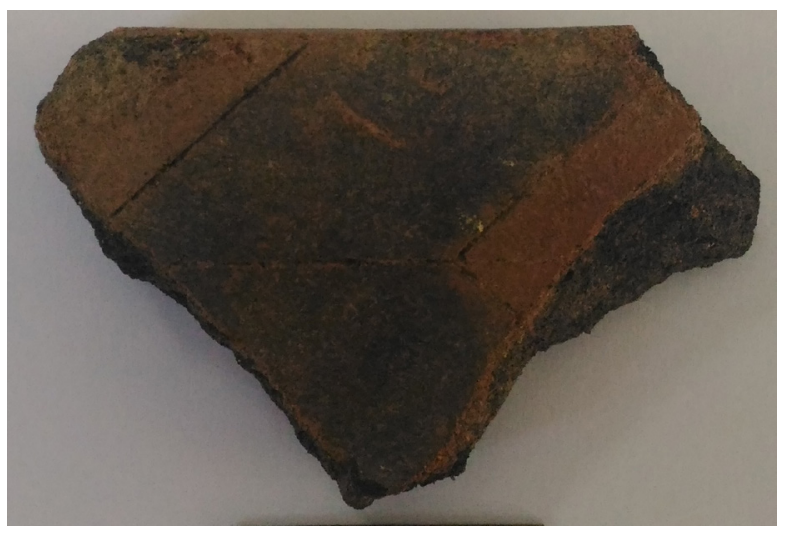

Gambar 7. Contoh pola hias 'painting' yang mengisi bidang dalam bingkai yang dibuat dengan teknik gores (Sumber: Dokumen Triwurjani 2018) 


\section{Lampiran 2.}

Tabel 1. Unsur-Unsur Tembikar Matano dengan Metode XRF

Contoh: Situs Pontada

\begin{tabular}{|c|c|c|}
\hline Unsur & ppm (part per million) & $\begin{array}{l}\text { Concentration } \\
\text { MA1 (Moving Average) }\end{array}$ \\
\hline NaKal & 1.998344197 & 0.259585769 \\
\hline MgKal & 2.076006895 & 0.869339256 \\
\hline AlKal & 3.509500024 & 1.423931987 \\
\hline SiKal & 51.90489891 & 13.27456778 \\
\hline PKal & 3.79237217 & 0.019915417 \\
\hline S Kal & 9.771694083 & 0.412654998 \\
\hline K Kal & 10.04894273 & 0.079251189 \\
\hline CaKal & 91.18196973 & 1.582528356 \\
\hline BaLal & 24.39045893 & -0.035088226 \\
\hline TiKal & 27.45894376 & 0.200106045 \\
\hline VKal & 17.48591027 & 0.033186829 \\
\hline CrKal & 37.37315103 & 0.041354413 \\
\hline MnKal & 57.79102307 & 0.185781878 \\
\hline FeKal & $3,250.28$ & 18.19039404 \\
\hline CoKal & 193.9104447 & 0.00692756 \\
\hline NiKal & 44.27608288 & 0.034203231 \\
\hline CuKal & 12.41345503 & 0.005420677 \\
\hline ZnKal & 10.7710945 & 0.003710224 \\
\hline $\begin{array}{l}\text { Sisi Sebaliknya } \\
\text { Unsur }\end{array}$ & ppm & Concentration MA1 \\
\hline NaKal & 1.711888042 & 0.502354699 \\
\hline MgKal & 1.963785494 & 0.577605864 \\
\hline AlKal & 3.608001667 & 1.659720319 \\
\hline SiKal & 41.62380313 & 11.17533311 \\
\hline PKal & 2.642587365 & -0.006040646 \\
\hline S Kal & 6.578905958 & 0.230116547 \\
\hline K Kal & 16.82468477 & 0.313494169 \\
\hline CaKal & 37.03693178 & 0.670572676 \\
\hline BaLal & 33.48469973 & -0.055862889 \\
\hline TiKal & 38.33055677 & 0.316886161 \\
\hline VKal & 17.0461832 & 0.015321021 \\
\hline CrKal & 26.69080564 & 0.029590406 \\
\hline MnKal & 44.42239148 & 0.121297767 \\
\hline FeKal & $2,065.44$ & 11.0916751 \\
\hline CoKal & 132.0850288 & 0.004481982 \\
\hline
\end{tabular}


PURBaWIDya $\square$ Vol. 7, No. 1, Juni 2018: $1-20$

\begin{tabular}{lll}
\hline NiKal & 43.4704216 & 0.033027298 \\
\hline CuKal & 12.13535565 & 0.005355045 \\
\hline ZnKal & 11.27472161 & 0.005362569 \\
\hline
\end{tabular}

Sumber: Hasil Penelitian XRF 2017 (sumber:

Triwurjani, 2017) 